\title{
Pengembangan Media Pembelajaran Matematika Video Interaktif berbasis Multimedia
}

\author{
Putri Utami Suseno $^{1 *}$, Yamin Ismail2, Sumarno Ismail ${ }^{3}$
}

\author{
1,2,3 Jurusan Matematika, Fakultas MIPA, Universitas Negeri Gorontalo, \\ Jl. Prof. Dr. Ing. B. J. Habibie, Tilongkabila, Kabupaten Bone Bolango, Gorontalo 96119, Indonesia
}

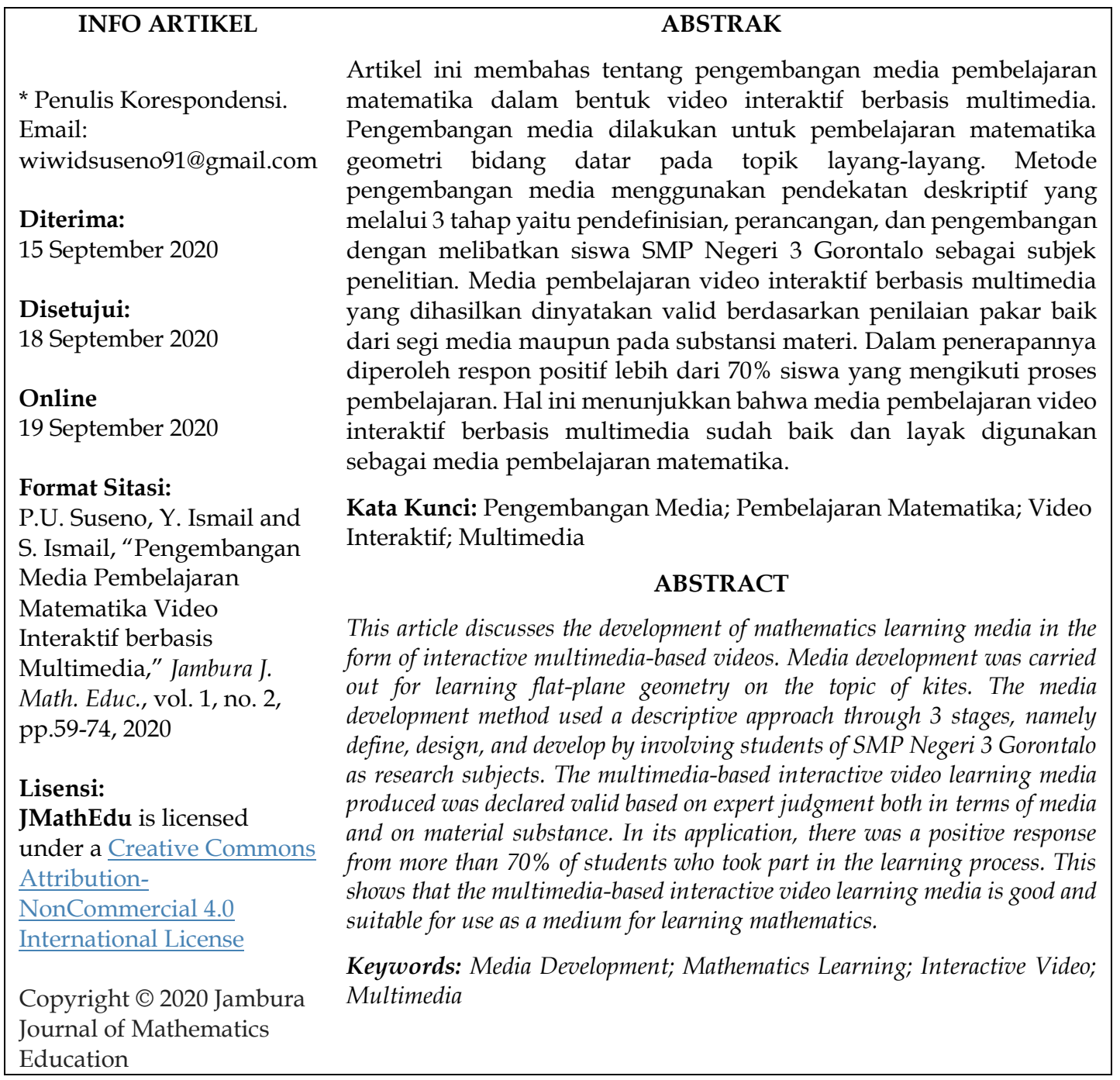

\section{Pendahuluan}

Guru sebagai pengajar, idealnya harus mampu mengelola proses pembelajaran yang dapat memotivasi siswa, kreatif dan selalu berinovasi dalam menyediakan bahan dan media belajar bagi siswa. Hal ini jelas sangat diperlukan apalagi dalam pembelajaran matematika, dimana kebanyakan siswa cepat jenuh mengikuti proses pembelajaran. Pada umumnya, anak di usia remaja atau awal usia sekolah menengah pertama (usia 11-12 tahun), pada aspek perkembangan kognitifnya terjadi peralihan antara tahap 
berpikir operasional konkrit ke operasional formal [1], artinya seorang anak belum bisa berpikir secara abstrak secara keseluruhan. Oleh karena itu, media pembelajaran sangat dibutuhkan untuk menunjang proses perkembangan kognitif anak di usia awal sekolah menengah pertama. Sama halnya dalam pembelajaran matematika, media dibutuhkan sebagai alat komunikasi antara guru dan murid untuk memperjelas konsep yang bersifat abstrak.

Salah satu aspek yang harus diperhatikan dalam memilih dan menggunakan media pembelajaran adalah tentang modalitas belajar anak [2]. Modalitas belajar merupakan potensi dasar atau kecenderungan yang dimiliki anak. Dengan modalitas belajar siswa yang variatif, seharusnya pemilihan media pembelajaran dari seorang guru tidak hanya terfokus pada salah satu modalitas saja, seperti yang pada umumnya terjadi. Jika ditinjau dari hal tersebut, maka seorang guru perlu mengombinasikan berbagai media dalam menyampaikan pesan sehingga pembelajaran akan lebih optimal. Perpaduan antara berbagai media sering disebut sebagai konsep multimedia [3]. Lebih lanjut dijelaskan bahwa dalam kamus Oxford-Advance Learner's Dictionary, disebutkan bahwa multimedia berarti involving several different methods of communication, yaitu melibatkan atau memasukkan berbagai metode berbeda dalam komunikasi. Hal ini menunjukkan bahwa melalui konsep multimedia, seorang guru berupaya agar rangsangan (stimulus) yang diterima siswa akan lebih banyak melalui penggunaan media yang beragam. Semakin banyak alat indera yang digunakan untuk menerima dan mengolah informasi, semakin besar kemungkinan informasi tersebut dimengerti dan dapat dipertahankan dalam ingatan [4].

Pola pengembangan media pembelajaran sebenarnya hingga saat ini masih menjadi topik yang banyak dilakukan oleh tenaga pendidik maupun peneliti. Beberapa peneliti melakukan pengembangan pada aspek modul pembelajaran untuk menunjang proses pembelajaran, seperti yang terdapat pada [5][6]. Selain itu, ada juga peneliti yang mencoba mengembangkan media pembelajaran dalam bentuk video seperti yang terdapat pada [7][8][9]. Termasuk salah satu upaya yang dilakukan untuk memperbaiki kualitan pembelajaran adalah dengan menggunakan media pembelajaran yang berbasis Information and Communication Technology (ICT) [10].

Banyaknya peneliti yang melakukan pengembangan media tentunya tidak menjadi titik akhir dalam upaya untuk menciptakan inovasi dalam pembelajaran. Oleh karena itu, dalam makalah ini dilakukan upaya lain dalam pengembangan media pembelajaran yakni dengan mengembangkan media belajar matematika dalam bentuk audio-visual yaitu video interaktif berbasis multimedia. video interaktif berbasis multimedia disajikan dengan gambar bergerak, berisi pesan atau informasi pembelajaran meliputi rangsangan yang variatif (audio-visual). Pembelajaran menggunakan media yang dikembangkan ini, memungkinkan terjadinya komunikasi lebih dari satu arah antara komponen-komponen komunikasi, dalam hal ini guru, media dan siswa. Hal ini diharapkan dapat membantu dalam materi yang membutuhkan visualisasi seperti geometri bidang datar. Dalam hal ini, akan dilakukan pengembangan media pembelajaran matematika video interaktif berbasis multimedia pada topik geometri bidang datar, khususnya pada topik layang-layang.

\section{Metode}

Metode penelitian yang digunakan dalam makalah ini adalah penelitian pengembangan dengan pendekatan deskriptif yang berorientasi pada pengembangan produk. 
Penelitian dilakukan untuk menghasilkan produk tertentu dan menguji keefektifan produk tersebut [11]. Desain penelitian pengembangan pada makalah ini mengacu pada model Four-D, yang terdiri dari 4 tahap pengembangan yaitu Define, Design, Develop, dan Disseminate atau diadaptasikan menjadi model $4 \mathrm{P}$, yaitu pendefinisian, perancangan, pengembangan, dan penyebaran [12].

Dalam implementasinya pada makalah ini, pengembangan model dilakukan hanya menggunakan 3 tahapan, yaitu pendefinisian, perancangan dam pengembangan. Desain 3 tahapa ini mengacu pada [13] dengan langkah-langkah sebagai berikut:

1. Penyederhanaan model dari empat tahap menjadi tiga tahap, yaitu pendefinisian (define), perancangan (design), dan pengembangan (develop). Tahap penyebaran (disseminate) tidak dilakukan karena tujuan penelitian ini adalah mengembangkan media pembelajaran yang baik.

2. Analisis konsep dan analisis tugas yang semula paralel, dirubah menjadi berurutan dari analisis konsep ke analisis tugas. Hal ini disebabkan karena dalam pelajaran matematika, materinya terstruktur, sehingga urutan tugas akan bergantung pada urutan konsep.

3. Istilah analisis konsep diganti dengan analisis materi. Materi memiliki cakupan yang lebih luas dari konsep.

4. Dalam tahapan pengembangan dilakukan uji keterbacaan dan audio-visual. Hal ini dilakukan karena yang dikembangkan adalah media berbasis video, sehingga uji komponen video diperlukan untuk mengetahui apakah siswa tertarik dan memahami isi video.

\subsection{Prosedur Pengembangan}

\subsubsection{Tahap Pendefinisian (Define)}

Tujuan tahap awal ini adalah menetapkan dan mendefinisikan syarat-syarat pembelajaran. Hal-hal yang dilakukan pada tahap ini antara lain;

a) Menentukan alternatif pembelajaran yang sesuai dan mempertimbangkan perlunya pengembangan video interaktif berbasis multimedia sebagai media pembelajaran.

b) Menelaah karakteristik siswa, meliputi modalitas belajar, pemilihan media, pemilihan format, sikap terhadap topik mata pelajaran, bahasa yang digunakan dan kognitif siswa.

c) Mengidentifikasi, merinci dan menyusun konsep-konsep utama pada materi layang-layang yang akan dipelajari siswa.

d) Mengindentifikasi tugas umum dan tugas khusus yang diperlukan dalam pembelajaran yang sesuai kurikulum.

e) Menentukan atau merumuskan tujuan-tujuan pembelajaran yang akan dicapai oleh siswa dan selanjutnya diintegrasikan dalam bentuk media pembelajaran.

\subsubsection{Tahap Perencanaan (Design)}

Tahap ini bertujuan untuk merancang media pembelajaran berdasarkan masalahmasalah yang ditemukan dalam pembelajaran. Hal-hal yang dilakukan pada tahapan ini antara lain; 
a) Pemilihan media yang tepat dalam menyajikan materi disesuaikan dengan analisis karakteristik siswa, analisis tugas dan materi serta kombinasi media lain yang digunakan.

b) Pemilihan format disesuaikan dengan faktor-faktor dalam materi pembelajaran, terdiri dari format mendesain isi, pemilihan media pembelajaran, dan sumber belajar.

c) Desain awal berupa rancangan video interaktif, yaitu pengembangan media pembelajaran matematika video interaktif berbasis multimedia pada materi geometri bidang datar layang-layang.

\subsubsection{Tahap Pengembangan (Develop)}

Tahapan ini bertujuan untuk menghasilkan produk media pembelajaran pembelajaran yang telah direvisi berdasarkan masukan ahli dan uji coba produk. Langkah-langkah yang dilakukan pada tahap ini antara lain;

a) Validasi ahli

Pada tahap ini, penilaian difokuskan pada isi, bahasa, kualitas gambar video, suara, ilustrasi dan kemanfaatan media berdasarkan materi. Para ahli diberikan lembar validasi dan draft I yang akan divalidasi. Lembar validasi berisi komentar, saran dan penilaian terhadap produk media pembelajaran video interaktif berbasis multimedia. Penilaian terdiri dari 4 kategori, yaitu tidak sesuai (nilai 1), kurang sesuai (nilai 2), sesuai (nilai 3), dan sangat sesuai (nilai 4). Hasil penilaian validator dianalisis dengan mempertimbangkan saran dan komentar validator. Hasil analisis dijadikan pedoman untuk merevisi draft I sehingga diperoleh draft II.

b) Uji keterbacaan dan audio-visual.

Uji keterbacaan dan audio-visual pada draft II dilakukan untuk melihat sejauh mana produk dapat terbaca dan dipahami (tulisan, video, ilustrasi, efek suara) oleh sisawa. Subjek penelitian uji keterbacaan dan audio-visual adalah 3 orang siswa. Masukan yang diperoleh dari hasil ini digunakan untuk merefisi draft II sehingga dihasilkan draft III yang akan digunakan untuk uji coba.

c) Uji coba

Uji coba dilakukan untuk memperoleh masukan langsung dari siswa terhadap pengembangan media pembelajaran video interaktif berbasis multimedia pada materi geometri bidang datar layang-layang. Hasil dari uji coba menjadi dasar untuk penyempurnaan draft III, menjadi media pembelajaran multimedia berbasis video yang baik dan berkualiatas.

\subsection{Teknik Pengumpulan Data}

Pengumpulan data dalam penelitian ini diperoleh dari hasil validasi ahli dan angket respon siswa.

a) Hasil Validasi

Angket lembar validasi media diberikan kepada ahli dari aspek media dan ahli dari aspek substansi materi. Hasil angket validasi media dimaksudkan untuk memperoleh data tentang kualitas media pembelajaran video interaktif berbasis multimedia. 
P.U. Suseno, dkk | Pengembangan Media Pembelajaran Matematika Video Interaktif ...

b) Hasil angket respon siswa

Hasil angket respon siswa digunakan untuk memperoleh data respon siswa terhadap media pembelajaran video interaktif berbasis multimedia.

\subsection{Teknik Analisis Data}

Analisis data yang dilakukan dalam penelitian ini adalah analisis deskriptif yang terdiri dari analisis lembar validasi dan analisis respon siswa.

a) Analisis Lembar Validasi

Para ahli media dan ahli materi sebagai validator menuliskan penilaiannya terhadap media pembelajaran multimedia berbasis video pada lembar validasi. Penilaian terdiri dari 4 kategori, yaitu sangat sesuai, sesuai, kurang sesuai, dan tidak sesuai. Data dari hasil penilaian para ahli kemudian dianalisis dengan mempertimbangkan saran, dan komentar dari validator. Hasil analisis ini kemuadian dijadikan sebagai pedoman dalam merevisi media pembelajaran video interaktif berbasis multimedia. Media pembelajaran dapat digunakan jika minimal validator memberikan penilaian dengan kategori minimal 'sesuai' .

b) Analisis respon siswa

Data respon siswa yang diperoleh dari hasil angket dianalisis persentasi dan kualifikasi untuk membuat kesimpulan apakah media interactive video berbasis multimedia dapat menumbuhkan motivasi belajar siswa dalam pembelajaran, dalam hal ini siswa merespon positif. Angket respon siswa terlebih dahulu divalidasi secara konstruktif.

Rumusan untuk menentukan persentase respon positif siswa dalam penggunaan media yaitu:

$$
\text { Persentase Respon Siswa }(R S)=\frac{\text { Jumlah Respon Tiap Aspek }}{\text { Jumlah Siswa }} \times 100 \%
$$

Hasil persentasi dengan kriteria positif yang mengacu pada Tabel 1.

Tabel 1: Kriteria interpretasi skor

\begin{tabular}{cl}
\hline Kriteria (\%) & \multicolumn{1}{c}{ Klasifikasi } \\
\hline $85 \%<R S \leq 100 \%$ & Sangat Positif \\
$70 \%<R S \leq 85 \%$ & Positif \\
$50 \%<R S \leq 70 \%$ & Kurang Positif \\
$0 \%<R S \leq 50 \%$ & Negatif \\
\hline \multicolumn{2}{c}{ Sumber: $[14]$}
\end{tabular}

\section{Hasil dan Pembahasan}

\subsection{Pendefenisian (Define)}

\subsubsection{Analisis Awal-Akhir}

Pada tahap ini dilakukan pengamatan dan wawancara secara langsung dengan guru matematika kelas VII di SMP Negeri 3 Gorontalo. Berdasarkan hasil pengamatan diperoleh informasi bahwa siswa pada umumnya cepat jenuh dengan pelajaran matematika dan kemauan belajarnya masih kurang. Siswa secara umum terkesan pasif dalam proses pembelajaran. Meskipun pada umumnya guru mengajar dengan metode 
konvensional, tetapi ada beberapa guru yang sudah menggunakan atau memanfaatkan media pembelajaran seperti Power Point agar siswa lebih aktif dalam pembelajaran. Namun penggunaan media Power Point sendiri masih belum memberikan efek positif, disebabkan isi materi pembelajaran dan tampilan yang kurang variatif, serta kurang mendukung modalitas belajar siswa yang beragam.

Hasil wawancara dengan guru kelas VII SMP Negeri 3 Gorontalo juga memberikan informasi bahwa pemahaman siswa tentang materi segi empat khususnya pada bangun layang-layang masih rendah, terutama untuk penurunan rumus luas dan keliling layang-layang. Siswa juga masih sulit menghafal dan memahami penjelasan rumus dari bangun layang-layang yang ada dalam buku paket.

Berdasarkan teori yang sudah dijelaskan sebelumnya bahwa semakin banyak indera yang digunakan atau dirangsang selama proses pembelajaran, maka materi yang disampaikan akan lebih mudah diingat, untuk itu diperlukan media pembelajaran yang sesuai [4]. Disamping itu, media pembelajaran yang digunakan harus bisa membuat siswa aktif dan senang dalam pelajaran matematika. Sebagai alternatif, media pembelajaran yang digunakan adalah media pembelajaran video interaktif berbasis multimedia. Oleh karena media pembelajaran di sekolah saat ini belum efektif, maka diperlukan pengembangan media pembelajaran video interaktif berbasis multimedia dalam pembelajaran matematika.

\subsubsection{Analisis Siswa}

Analisis ini dilakukan melalui wawancara dengan guru matematika dan wali kelas VII SMP Negeri 3 Gorontalo. Analisis ini bertujuan untuk menelaah karakteristik siswa yang meliputi latar belakang sosial budaya, tingkat perkembangan kognitif, dan pengetahuan siswa. Dari analisis ini ditemukan beberapa hal sebagai berikut:

a) Latar belakang sosial budaya siswa beragam. Pekerjaan orang tua siswa antara lain, wiraswasta, Guru, PNS, pedagang, dan lain-lain. Lingkungan sekolah dan tempat tinggal siswa berada di daerah perkotaan kota gorontalo.

b) Usia siswa kelas VII SMP Negeri 3 Gorontalo sekitar 11-12 tahun. Seperti yang sudah dikemukaan pada bab sebelumnya, jika ditinjau dari teori perkembangan kognitif maka siswa-siswa ini berada dalam tahap peralihan dari tahap operasional konkrit ke operasional formal.

c) Berdasarkan latar belakang pengetahuan siswa, sub materi segi empat dalam hal ini bangun layang-layang yang dipelajari siswa kelas VII SMP Negeri 3 Gorontalo bukan merupakan materi baru, sebab sudah pernah dipelajari di kelas tingkat Sekolah Dasar (SD).

d) Siswa belum pernah mengikuti pembelajaran matematika dengan menggunakan media Video Interaktif berbasis multimedia.

\subsubsection{Analisis Materi}

Analisis materi bertujuan untuk mengidentifikasi bagian-bagian materi yang akan dipelajari siswa pada sub materi segi empat dalam hal ini bangun layang-layang. Dalam hal ini, materi mengacu pada kurikulum K13 untuk kelas VII SMP. Analisi materi disajikan dalam bentuk diagram seperti yang ditampilkan pada Gambar 1. 
P.U. Suseno, dkk | Pengembangan Media Pembelajaran Matematika Video Interaktif ...

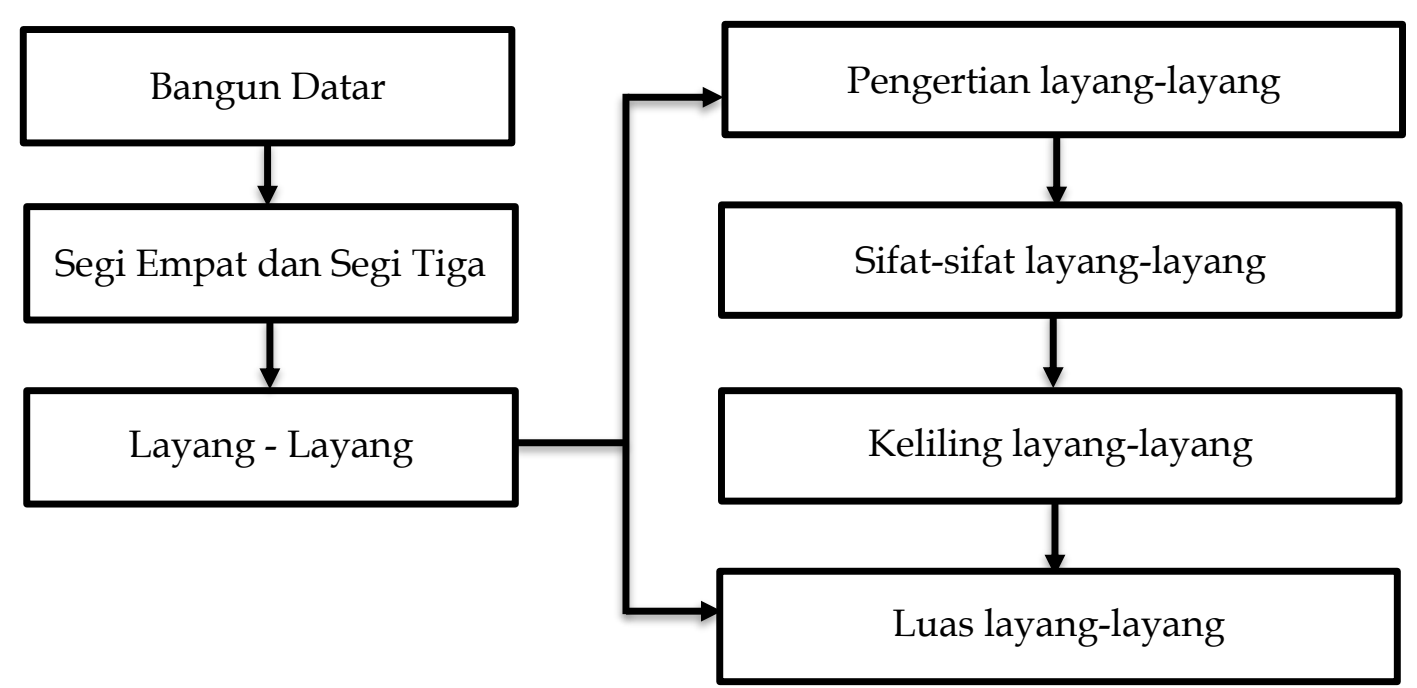

Gambar 1. Bagan analisis sub materi segi empat pada bangun datar layang-layang

\subsubsection{Analisis Tugas}

Analisis tugas meliputi tugas umum dan khusus. Tugas umum mengacu pada standar kompetensi unit geometri dalam K13. Adapun tugas khusus mengacu pada indikator pencapaian hasil belajar. Hasil analisis tugas untuk sub materisegi empat pada bangun layang-layang di kelas VII SMP adalah sebagai berikut :

a) Tugas Umum (Standar Kompetensi)

Memahami konsep segi empat dan segitiga serta menentukan ukurannya.

b) Tugas Khusus (Indikator)

1) Menjelaskan pengertian segi empat ditinjau dari sisi, sudut, dan diagonalnya.

2) Menjelaskan sifat-sifat segi empat ditinjau dari sisi, sudut, dan diagonalnya.

3) Menurunkan rumus luas bangun segitiga dan segi empat.

4) Menyelesaikan masalah yang berkaitan dengan keliling dan luas bangun segitiga dan segi empat.

\subsubsection{Spesifiksi Tujuan Pembelajaran}

Spesifikasi tujuan pembelajaran merupakan penjabaran hasil dari analisis materi dan analisis tugas menjadi indikator pencapaian hasil belajar. Hal ini dijabarkan secara spesifik sebagai berikut;

a) Siswa dapat menjelaskan pengertian layang-layang ditinjau dari sisi, sudut, dan diagonalnya.

b) Siswa dapat menjelaskan sifat-sifat layang-layang ditinjau dari sisi, sudut, dan diagonalnya.

c) Siswa dapat menyelesaikan masalah yang berkaitan dengan keliling layanglayang.

d) Siswa dapat menyelesaikan masalah yang berkaitan dengan luas layang-layang. 


\subsection{Perancanaan (Design)}

\subsubsection{Pemilihan Media}

Berdasarkan analisis tugas, materi, dan sarana yang tersedia di SMP Negeri 3 Gorontalo, beberapa media pembelajaran yang dipilih adalah papan tulis, spidol, Proyektor (LCD), penggaris, kertas HVS, Sound Speacker, kabel roll, pointer, gunting, laptop, dan busur.

\subsubsection{Pemilihan Format}

Dalam merancang media Video Interaktif, dipilih format isi yang sesuai dengan kurikulum K13, standar kompetensi, kompetensi dasar, dan indikator. Perancangan format media Video Interaktif terdiri dari materi, kesimpulan serta latihan soal yang dibuat semenarik mungkin dengan tujuan agar siswa tidak jenuh dan dapat berpartisipasi secara aktif selama pembelajaran.

\subsubsection{Rancangan Awal}

Rancangan awal yang dimaksud dalam penelitian ini adalah seluruh kegiatan yang harus dilakukan sebelum pelaksanaan uji coba. Hasil dari tahap ini adalah rancangan awal media Video Interaktif berbasis multimedia yang disusun sebagai draft I, beserta instrument penelitian.

Rancangan naskah selanjutnya dituangkan dalam gambar nyata, yang disebut dengan Storyboard atau storyline. Elemen - elemen yang dijabarkan dalam storyboard antara lain scene/adegan, durasi (waktu), sound effect, naskah beserta gambaran adegan, effect transition. Storyboard memberikan gambaran secara jelas tahapan-tahapan dalam pembuatan media video interaktif. Rancangan storyboard media yang dibuat dalam pengembangan media video interaktif disajikan pada Tabel 2.

Tabel 2: Storyboard media video interaktif

\begin{tabular}{|c|c|c|c|c|c|}
\hline Scene & Board & Durasi & Sound & Naskah & $\begin{array}{c}\text { Efek/ } \\
\text { Transisi }\end{array}$ \\
\hline 1. & & 20 detik & $\begin{array}{l}\text { Akusti } \\
\text { k gitar } \\
\text { "energ } \\
\text { ic" }\end{array}$ & $\begin{array}{l}\text { Intro : Menampilkan } \\
\text { foto layang-layang, } \\
\text { berbagai model dan } \\
\text { bentuk layang-layang } \\
\text { dalam kehidupan } \\
\text { sehari-hari. } \\
\text { Teks : Layang-layang }\end{array}$ & $\begin{array}{c}3 D \\
\text { Cascade, } \\
\text { fade offset, } \\
\text { page lope. }\end{array}$ \\
\hline 2. & & 18 detik & $\begin{array}{l}\text { Akusti } \\
\text { k gitar } \\
\text { "energ } \\
\text { ic" }\end{array}$ & $\begin{array}{c}\text { Intro } \\
\text { Pengenalan tokoh : } \\
\text { Pemain } 1: \text { Iki } \\
\text { Pemain } 2: \text { Fadila } \\
\text { Pemain } 3: \text { Ical }\end{array}$ & $\begin{array}{c}\text { Page loop, } \\
\text { fade offset, } \\
\text { barn door, } \\
\text { portals }\end{array}$ \\
\hline
\end{tabular}


P.U. Suseno, dkk | Pengembangan Media Pembelajaran Matematika Video Interaktif ...

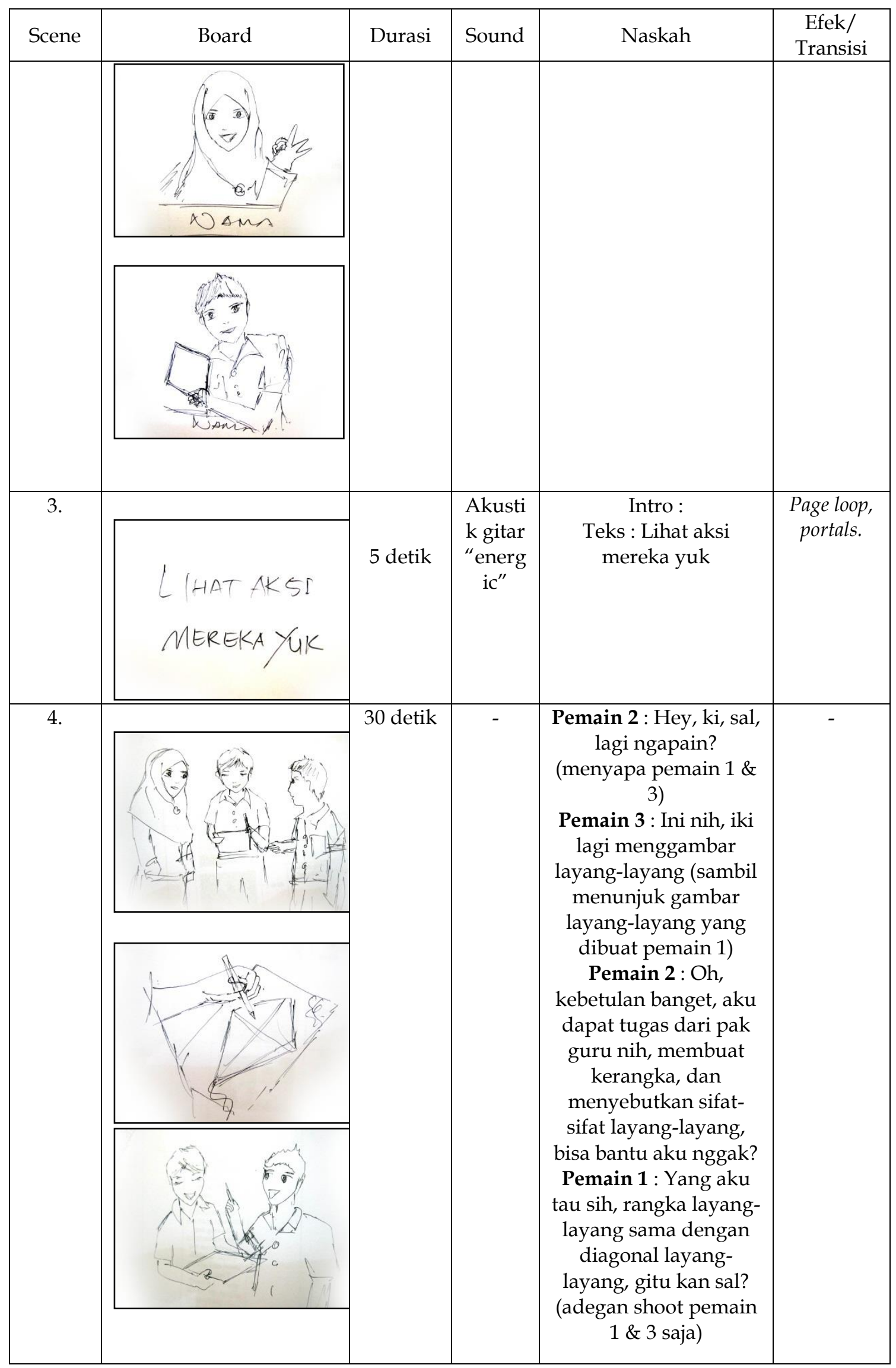


P.U. Suseno, dkk | Pengembangan Media Pembelajaran Matematika Video Interaktif ...

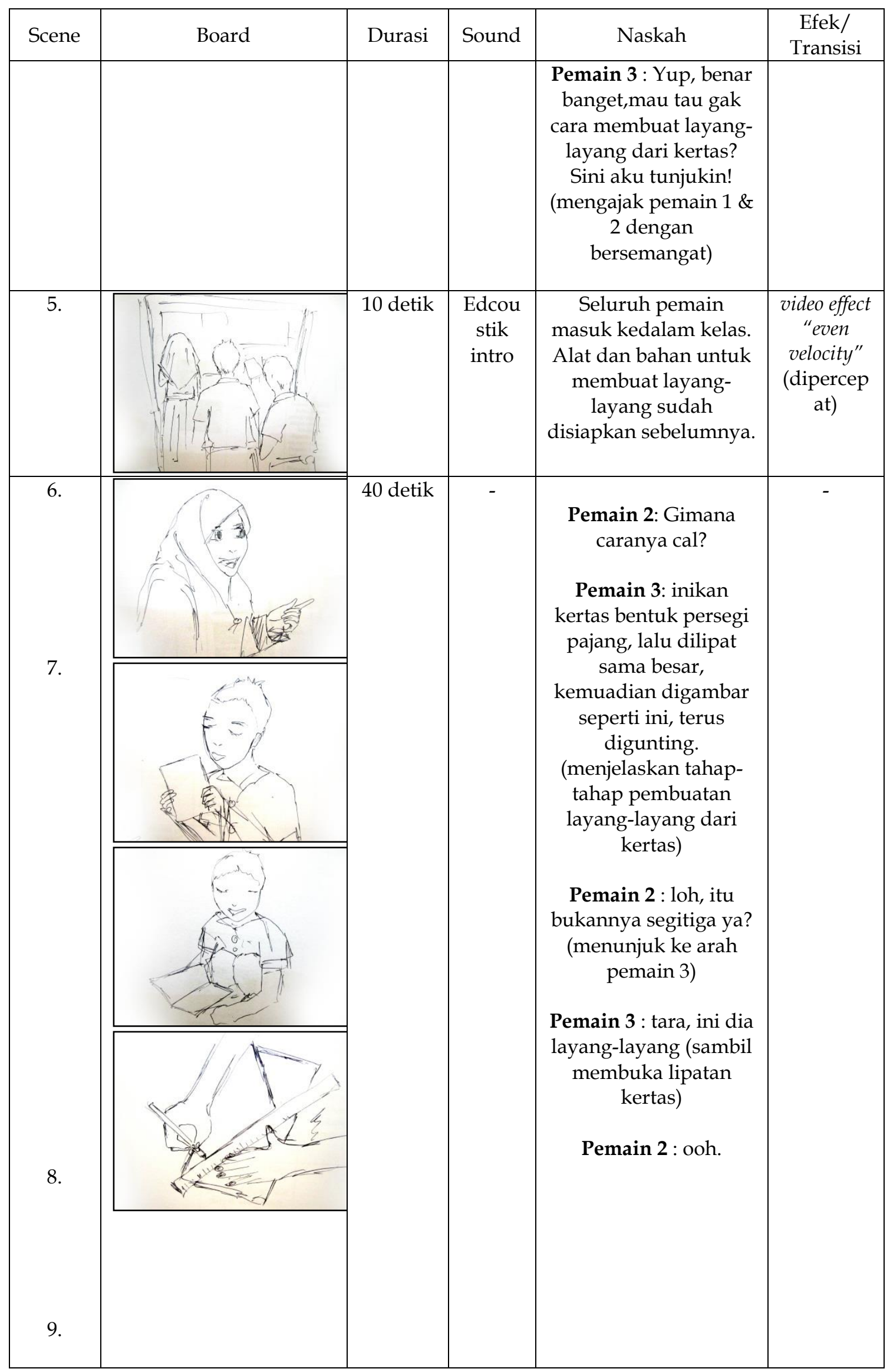


P.U. Suseno, dkk | Pengembangan Media Pembelajaran Matematika Video Interaktif ...

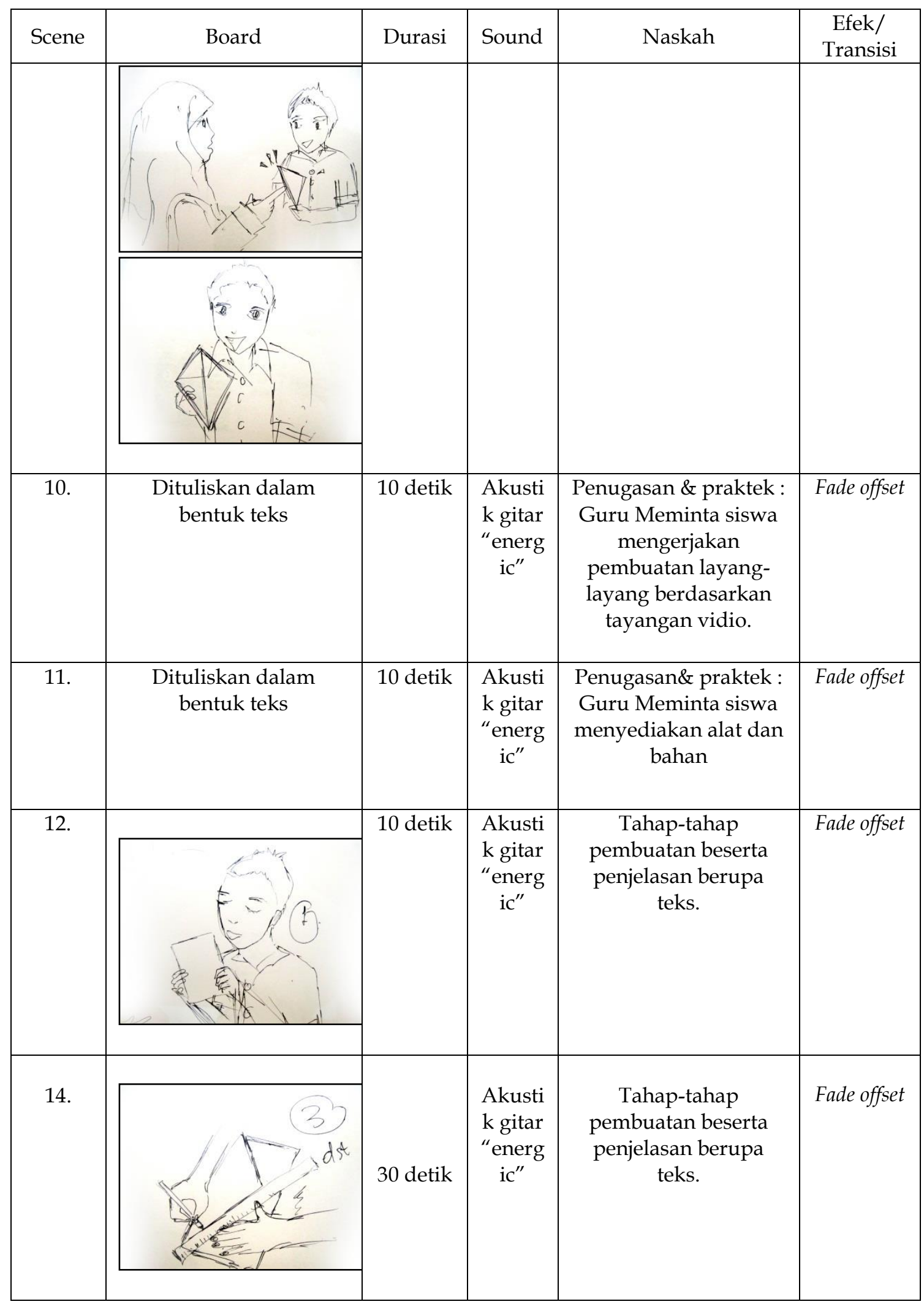


P.U. Suseno, dkk | Pengembangan Media Pembelajaran Matematika Video Interaktif ...

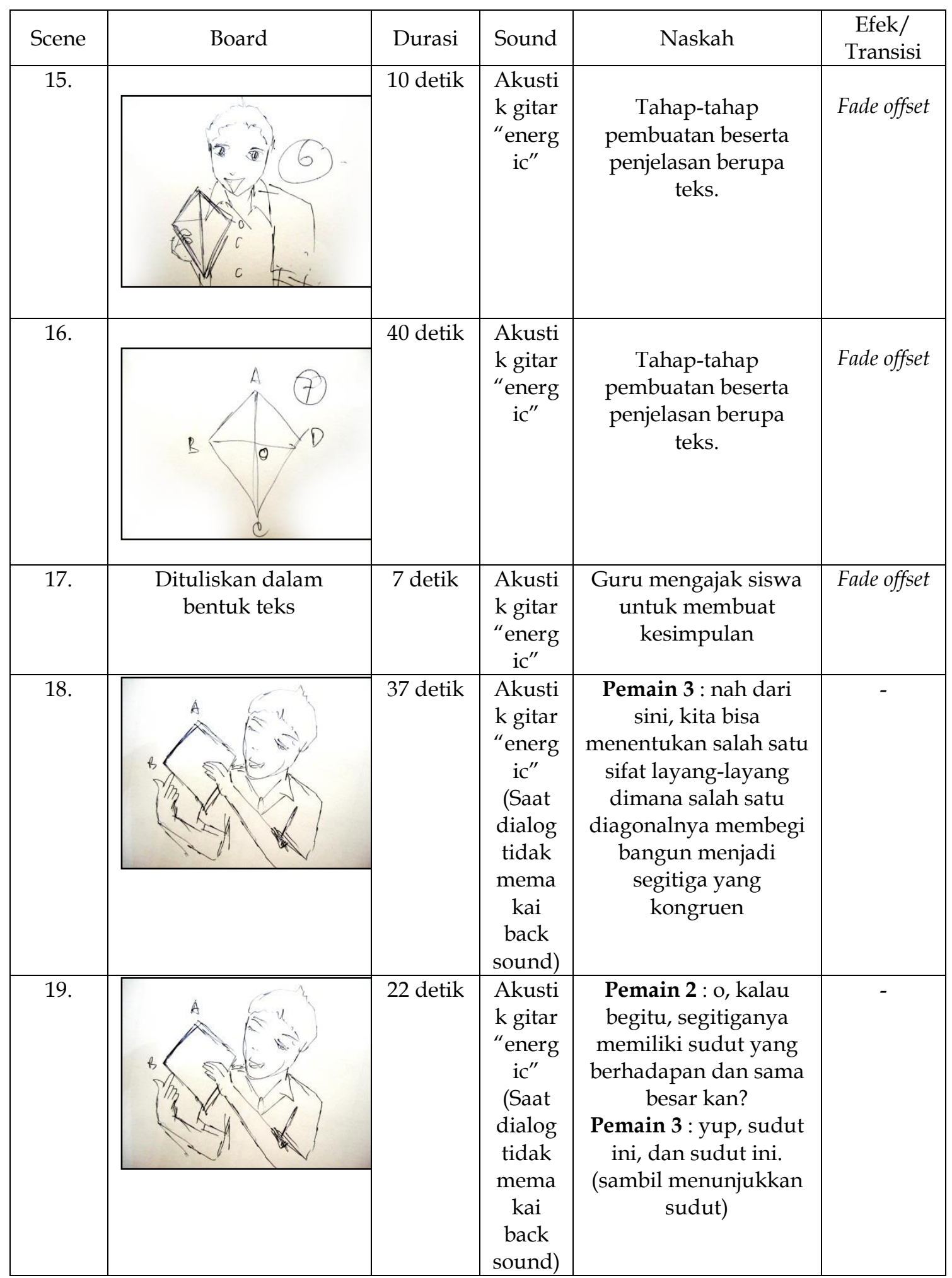


P.U. Suseno, dkk | Pengembangan Media Pembelajaran Matematika Video Interaktif ...

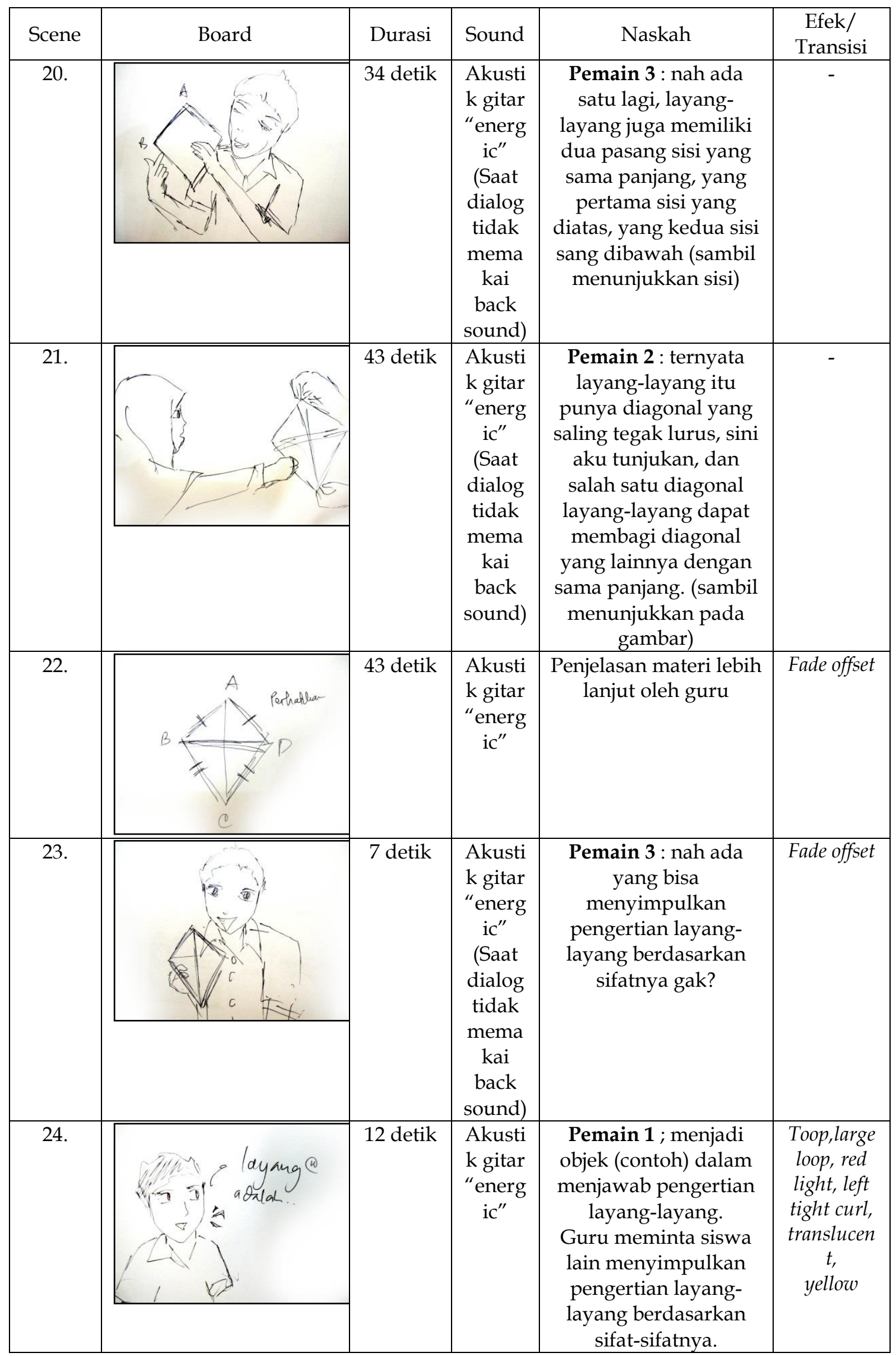


P.U. Suseno, dkk | Pengembangan Media Pembelajaran Matematika Video Interaktif ...

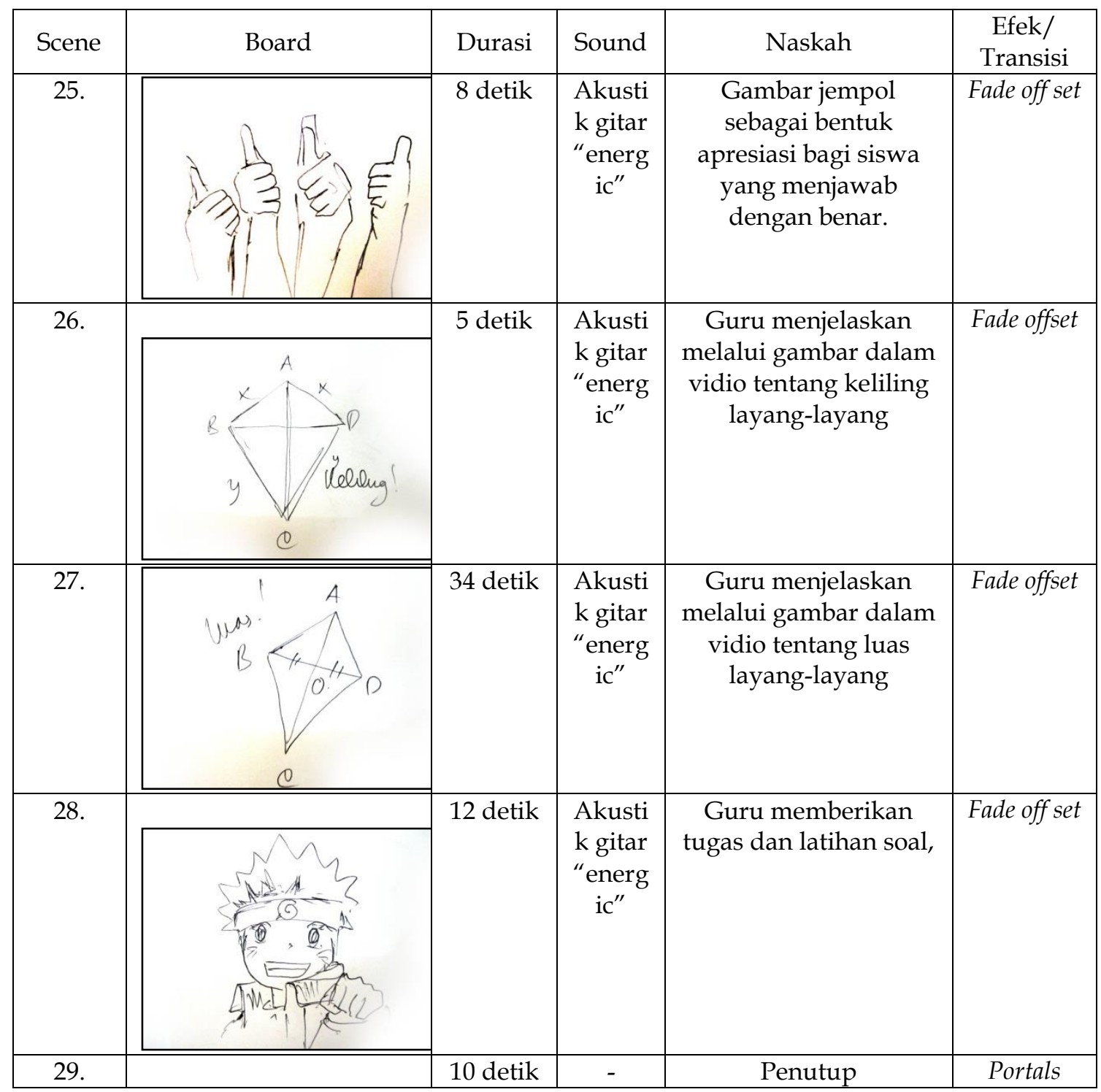

Naskah video yang sudah dijabarkan dalam Storyboard, selanjutnya dijadikan acuan bagi sutradara dan pemain dalam pembuatan video. Storyboard juga akan disertakan beserta lembar penilaian validasi ahli dalam proses validasi media video interaktif.

\subsection{Pengembangan (Develop)}

Hasil rancangan awal dinilai oleh validator berdasarkan indikator; keefektifan desain, konsistensi, format, bahasa, organisasi dan kemanfaatan. Hasil validasi ahli berupa kritik dan saran perbaikan dijadikan sebagai dasar untuk memperbaiki produk video yang dikembangkan. Media pembelajaran hasil revisi berdasarkan masukan dinyatakan valid dengan penilain minimal 'sesuai' dan dan dapat digunakan pada tahap selanjutnya, yakni uji coba produk.

\subsection{Uji Coba Produk dan Respon Siswa}

Uji coba terbatas dilakukan untuk memperoleh masukan langsung dari siswa tentang media pembelajaran video interaktif berbasis multimedia sehingga hasilnya dijadikan 
dasar penyempurnaan produk. Dalam hal ini dilibatka 29 orang siswa SMP Negeri 3 Gorontalo sebagai subjek.

Tahap uji coba terbatas terdiri dari tahap persiapan, pelaksanaan, dan penutup. Pada tahap persiapan, disiapkan semua media yang di gunakan dalam proses pembelajaran. Setiap siswa menyiapkan alat dan bahan untuk membuat layang-layang dari kertas. Pada tahap pelaksanaan, materi yang diajarkan disajikan dalam bentuk video interaktif. Video tidak ditampilkan secara keseluruhan dari awal sampai akhir, sebab pada bagianbagian tertentu siswa membutuhkan jeda dan guru harus menjelaskan materi pembelajaran agar siswa bisa memahami pelajaran dengan baik.

Setelah satu tahap selesai dilaksanakan, video dilanjutkan kembali untuk memulai tahapan selanjutnya. Begitu juga dengan materi yang ditampilkan dalam video interaktif, pada bagian-bagian tertentu guru membuat jeda dan menjelaskan materi secara lebih terperinci untuk memastikan pemahaman siswa terhadap materi pembelajaran.

Setelah pembelajaran dengan media pembelajaran video interaktif berbasis multimedia selesai, siswa dibagikan angket respon yang sebelumnya telah divalidasi secara konstruktif. Selanjutnya data yang diperoleh dari uji coba ini kemudian dianalisis dalam bentuk persentase. Hasil analisis dijadikan sebagai pertimbangan untuk menghasilkan media pembelajaran video interaktif berbasis multimedia yang baik dan berkualitas, yang dapat digunakan sebagai media pembelajaran matematika kelas VII SMP. Hasil analisis data respon siswa menggambarkan bahwa persentase rata-rata respon siswa untuk masing-masing adalah lebih dari $70 \%$. Hal ini menunjukkan adanya respon positif siswa terhadap penggunaan media berupa video interaktif berbasis multimedia dalam proses pembelajaran. Dengan demikian, produk media pembelajaran video interaktif berbasis multimedia dapat digunakan dalam pembelajaran matematika sebagai media yang baik dan berkualitas.

\section{Kesimpulan}

Media pembelajaran matematika video interaktif berbasis multimedia pada materi layang-layang, telah dikembangkan dengan menggunakan tiga tahapan yaitu define, design dan develop. Media yang dihasilkan telah divalidasi dan diujicobakan dengan menghasilkan lebih dari $70 \%$ siswa memberikan respon positif. Dengan demikian, media yang dikembangkan dapat digunakan sebagai media pembelajaran matematika pada topik bidang datar layang-layang.

\section{Referensi}

[1] D. A. Bujuri, "Analisis Perkembangan Kognitif Anak Usia Dasar dan Implikasinya dalam Kegiatan Belajar Mengajar," Literasi, vol. 9, no. 1, pp. 37-50, 2018.

[2] Musfiqon, Pengembangan Media \& Sumber Pembelajaran. Jakarta: Prestasi Pustaka Publisher, 2012.

[3] D. Sugianto, A. G. Abdullah, S. Elvyanti, and Y. Muladi, "Modul Virtual: Multimedia Flipbook Dasar Teknik Digital," Innov. Vocat. Technol. Educ., vol. 9, no. 2, Feb. 2017, doi: 10.17509/invotec.v9i2.4860.

[4] A. Arsyad, Media Pembelajaran. Jakarta: PT Rajagrafindo Persada, 2002.

[5] S. Wahyuni, M. Yati, and A. Fadila, "Pengembangan Modul Matematika Berbasis REACT terhadap Kemampuan Komunikasi Matematis Peserta Didik," Jambura J. 
P.U. Suseno, dkk | Pengembangan Media Pembelajaran Matematika Video Interaktif ...

Math. Educ., vol. 1, no. 1, pp. 1-12, Feb. 2020, doi: 10.34312/jmathedu.v1i1.4542.

[6] N. Saputri, I. N. Azizah, and H. Hernisawati, "Pengembangan Bahan Ajar Modul dengan Pendekatan Discovery Learning pada Materi Himpunan," Jambura J. Math. Educ., vol. 1, no. 2, pp. 1-11, 2020, doi: 10.34312/jmathedu.v1i2.5594.

[7] S. D. Tamu, E. Hulukati, and I. Djakaria, "Pengembangan Modul dan Video Pembelajaran Matematika Persiapan Ujian Nasional pada Materi Dimensi Tiga," Jambura J. Math. Educ., vol. 1, no. 1, pp. 21-31, Mar. 2020, doi: 10.34312/jmathedu.v1i1.4558.

[8] S. Khadijah, S. Ismail, and R. Resmawan, "Pengembangan Bahan Ajar Berbasis Penalaran pada Materi Sudut Pusat dan Sudut Keliling Lingkaran," Al-Khwarizmi J. Pendidik. Mat. dan Ilmu Pengetah. Alam, vol. 8, no. 1, pp. 1-12, Apr. 2020, doi: 10.24256/jpmipa.v8i1.838.

[9] V. Damopolii, N. Bito, and R. Resmawan, "Efektifitas Media Pembelajaran berbasis Multimedia pada Materi Segiempat," Algoritm. J. Math. Educ., vol. 1, no. 2, pp. 74-85, 2019, doi: 10.15408/ajme.v1i1.

[10] D. Wungguli and L. Yahya, "Pengaruh Penggunaan Media Berbasis Information and Communication Technology (ICT) terhadap Hasil Belajar Siswa pada Materi Dimensi Tiga," Jambura J. Math. Educ., vol. 1, no. 1, pp. 41-47, Mar. 2020, doi: 10.34312/jmathedu.v1i1.5376.

[11] S. Sugiono, Metode Penelitian Kuantitatif Kualitatif dan RED. Bandung: Alfabeta, 2012.

[12] A. Rudiansyah, "Pengembangan Media Komik Pembelajaran Matematika Pada sub pokok Bahasan Operasi Hitung Pecahan Kelas V SD," Universitas Negeri Gorontalo, 2012.

[13] N. Bito, "Pembelajaran Berdasarkan Masalah untuk Sub Materi Pokok Prisma dan Limas Di Kelas VIII SMP Negeri 11 Gorontalo," Universitas Negeri Surabaya, 2009.

[14] A. J. Panawar, "Pengembangan Instrumen Tes Berbantu Media Komputer pada Pembelajaran Matematika Materi Trigonometri Kelas X SMA," Universitas Negeri Gorontalo, 2012. 